\title{
Antioxidant and antimicrobial properties of ethanolic extracts of guarana, boldo, rosemary and cinnamon
}

\author{
Propriedades antioxidante e antimicrobiana de extratos etanólicos de guaraná, boldo, \\ alecrim e canela
}

\author{
Jeannine Bonilla ${ }^{1 *}$, Paulo Jose do Amaral Sobral ${ }^{1}$ \\ 1 Universidade de São Paulo (USP), Faculdade de Zootecnia, Pirassununga/SP - Brazil
}

\section{${ }^{*}$ Corresponding Author}

Jeannine Bonilla, Universidade de São Paulo (USP), Faculdade de Zootecnia, Avenida Duque de Caxias Norte, 225, CEP: 13635-900, Pirassununga/ SP - Brazil, e-mail: jeanninebonilla@usp.br

Cite as: Antioxidant and antimicrobial properties of ethanolic extracts of guarana, boldo, rosemary and cinnamon. Braz. J. Food Technol., v. 20, e2016024, 2017

Received: Jan. 18, 2016; Accepted: May 02, 2017

\section{Abstract}

In this investigation, the ethanolic extracts of two less known plants, little reported in the literature (guarana and boldo leaves) were studied in comparison with the ethanolic extracts of two well studied plants (cinnamon and rosemary), regarding their colour, GC-MS profile, phenolic content and their antioxidant and antimicrobial properties. The rosemary $(59.20 \pm 0.28)$ and guarana $(56.63 \pm 0.54)$ extracts showed the highest values for luminosity $\left(L^{*}\right)$ and the UV-Vis absorption increased when $L^{*}$ decreased. GC-MS identified a limited number of compounds in the cinnamon and guarana extracts. The cinnamon extract showed the highest value for the total phenolic content (172 mg GA/g extract) as compared to the other extracts. The highest antioxidant capacity was observed for the boldo leaves extract in the TEAC $(6.66 \pm 0.17 \mathrm{mM})$ assay and for the rosemary extract in the DPPH $(0.80 \pm 0.14 \mathrm{mg} / \mathrm{L})$ test. In addition, all the extracts showed antimicrobial activity against the $S$. aureus strain, indicating that all the extracts studied could be used by food industries to develop new active food packaging materials.

Keywords: Herbs; Seeds; Phenols; Volatile compounds; S. aureus; E. coli.

\section{Resumo}

Nesta investigação, foram estudados dois extratos etanólicos de plantas pouco conhecidas na literatura (guaraná e boldo-do-chile), em comparação com os extratos etanólicos de duas plantas bastante estudadas (canela e alecrim), quanto aos parâmetros de cor, perfil GC-MS, teor fenólico e propriedades antioxidantes e antimicrobianas. Os extratos de alecrim $(59,20 \pm 0,28)$ e guaraná $(56,63 \pm 0,54)$ mostraram os maiores valores de luminosidade $\left(L^{*}\right)$. A absorção de radiação ultravioleta visível (UV-Vis) aumentou de intensidade quando o valor $L^{*}$ diminuiu. $\mathrm{Na}$ análise do perfil GC-MS, identificou-se um número limitado de compostos nos extratos de canela e guaraná. O extrato de canela apresentou o maior conteúdo de compostos fenólicos totais (172 mg GA/g extrato), em comparação com outros extratos. A maior capacidade antioxidante foi observada para o extrato de boldo-do-chile, no ensaio TEAC $(6,66 \pm 0,17 \mathrm{mM})$, e para o extrato de alecrim, no teste de $\operatorname{DPPH}(0,80 \pm 0,14 \mathrm{mg} / \mathrm{L})$. Adicionalmente, todos os extratos mostraram atividade antimicrobiana contra a cepa $S$. aureus, indicando que todos os extratos estudados podem ser utilizados pelas indústrias de alimentos para desenvolver novos materiais ativos de embalagem de alimentos.

Palavras-chave: Ervas; Sementes; Fenóis; Compostos voláteis; S. aureus; E. coli. 


\section{Introduction}

The great consumer demand for safe, high-quality foods can be attributed, in part, to well-known health quality data, and the availability and accessibility to information. This raises considerable challenges, particularly since there is increasing unease regarding the use of chemical preservatives and artificial antimicrobials to inactivate or inhibit spoilage and the growth of pathogenic microorganisms (TAJKARIMI et al., 2010)

Spices and herbs are well known for their antimicrobial and antioxidant properties, besides having the ability to produce multidimensional flavours in food (BONILLA et al., 2012; HOQUE et al., 2011; TONGNUANCHAN et al., 2012). Weerakkody et al. (2010) concluded that there was a highly positive linear relationship between the antioxidant and antibacterial activities and the total phenolic content in some spices and herbs. According to Moure et al. (2001), of the different parts of the plant, the leaves deserve especial attention, as well as the roots and seeds, due to their antioxidant activity, detected and reported in several studies.

The antimicrobial and antioxidant activities of extracts from non-conventional plants, such as Guarana (Paullinia cupana) and boldo leaves (Peumus boldus molina), are less reported in the literature. Guarana is a native Brazilian plant, the seeds being the only part suitable for human consumption. It is the richest vegetable source of caffeine (MAJHENIC et al., 2007), and the seeds contain bioactive components (phenols, proanthocyanidins, caffeine and catechins) with antioxidant and antimicrobial properties of interest to the food, pharmaceutical and cosmetic industries (SCHIMPL et al., 2013). On the other hand, boldo leaves is an endemic Chilean plant. The phenolic constituents (mainly proanthocyanidins and flavonol glycosides), alkaloids and essential oils are the main bioactive compounds of the boldo leaf extracts (VALLE et al., 2004; GIRARDI et al., 2016), and possess GRAS status conferred by the Food and Drug Administration (FDA)

Conventional plants such as cinnamon and rosemary are considered to be the most common spices and herbs with strong antimicrobial and/or antioxidant activity, due to the presence of cinnamaldehyde and camphor, respectively, identified as the major chemical components in these herbs (BUBONJA-SONJE et al., 2011; GIBIS; WEISS, 2012; MATHEW; ABRAHAM, 2006).

The extraction of active plant compounds is usually carried out using aqueous (water) or organic (ethanol) solvents. The next steps include the separation, identification and quantification of the phytochemicals, usually carried out using modern chromatographic analytical techniques (such as gas chromatography (GC), liquid chromatography (LC) and capillary electrophoresis (CE) (PAPETTI, 2012).

The main objective of this investigation was to study the antimicrobial and antioxidant activities of the ethanolic extracts of two less known plants, little reported in the literature (guarana and boldo leaves) in comparison with the ethanolic extracts of two common plants (cinnamon and rosemary), used as references since they possess well-known antimicrobial and antioxidant properties. Likewise, the volatile compounds, total phenolic contents and the colour of all the extracts were determined and studied, since they have been used as active ingredients in biodegradable edible films (BONILLA; SOBRAL, 2016, 2017).

\section{Material and methods}

\subsection{Plant material}

Four plant materials were chosen for this study: guarana seeds (Paullinia cupana, batch: 051182, colour: brown, moisture content: $3.0 \%$, total ash: $4.9 \%$ ), boldo leaves (Peumus boldus Molina, batch: 051983, colour: greenish, moisture content: $9.3 \%$, total ash: $11.5 \%$ ), cinnamon bark (Cinnamomum ssp., batch: 047272, colour: reddish-brown, moisture content: 5.5\%, total ash: 10.0\%) and rosemary leaves (Rosmarinus officinalis, batch: 051626, colour: greenish, moisture content: $8.7 \%$, total ash: $6.4 \%$ ). All the plant materials were purchased from the company Florien, Insumos Farmacéuticos (Piracicaba, Brazil).

\subsection{Extract preparations}

The plant extracts were prepared according to the method of Hoque et al. (2011). To standardize the extraction, the dried leaves, seeds and bark were first ground using a pestle and mortar. The ground powders ( $25 \mathrm{~g}$ of each) were mixed with absolute ethanol using a powder/solvent ratio of $1: 8(\mathrm{w} / \mathrm{v})$ and stirred continuously at room temperature for $4 \mathrm{~h}$. The mixtures $(200 \mathrm{~mL})$ were then centrifuged at $4000 \mathrm{rpm}$ for $10 \mathrm{~min}$ at $20^{\circ} \mathrm{C}$ in a Thermo Scientific IEC ${ }^{\text {TM }}$ Centra-GP8 centrifuge (USA) to remove undissolved debris, and the supernatants collected and filtered through filter paper (Whatman 1, USA). Subsequently, all the extracts were placed in amber bottles, tightly closed, and stored at refrigeration temperature $\left(4^{\circ} \mathrm{C}\right)$ for one month.

\subsection{Optical properties: colour}

The colour of the extracts was measured using a MiniScan MSEZ 1049 (BrasEq, São Paulo, Brazil) colorimeter with a spectral range from 400 to $700 \mathrm{~nm}$. The CIEL*a*b* coordinates were obtained from the reflection spectra of the samples. All measurements were carried out at least in triplicate.

\subsection{Ultraviolet-visible (UV-Vis) absorption}

UV-Vis absorption spectra of all the extracts without any prior treatment were recorded in the wavelength range of 250-700 nm using a UV-Vis spectrophotometer (PerkinElmer's LAMBDA35, USA). 


\subsection{Gas Chromatography/Mass Spectrometry (GC-MS) profile}

The extract components were identified by GC-MS using a GC-2010 gas chromatograph (Shimadzu, Suzhou, China) equipped with a GCMS-QP2010 Ultra mass spectrometer (Shimadzu, Suzhou, China). The column was an Agilent HP-5MS, 19091S-433 capillary column, $30 \mathrm{~m} \times 0.25 \mathrm{~mm}$ i.d. with a $0.25 \mu \mathrm{m}$ phase thickness. The injector temperature was $250{ }^{\circ} \mathrm{C}$ and $1 \mu$ of each sample was injected in the split mode $(1: 10)$. The oven temperature was maintained at $40^{\circ} \mathrm{C}$ for $3 \mathrm{~min}$, and then increased to $280^{\circ} \mathrm{C}$ at a rate of $8{ }^{\circ} \mathrm{C} / \mathrm{min}$, giving a total time of $60.5 \mathrm{~min}$. Helium was used as the carrier gas at a flow rate of $14 \mathrm{~mL} / \mathrm{min}$. The volatile extract compounds were identified by comparison with mass spectra from the Wiley 229 library, according to Wang et al. (2009). The GC-MS analyses were carried out in quadruplicate.

\subsection{Antioxidant activity}

\subsubsection{TEAC (Trolox Equivalent Antioxidant Capacity) assay}

The antioxidant capacity of all the extracts was determined using the spectrophotometric method described by Re et al. (1999), with Trolox (6-hydroxy-2, 5, 7, 8-tetramethylchroman-2-carboxylic acid) as the standard antioxidant. ABTS (2,20-azinobis(3-ethylbenzothiazoline-6sulfonic acid) was dissolved in water at $7 \mathrm{mM}$ and allowed to react with a $2.45 \mathrm{mM}$ potassium persulfate solution in the dark for $16 \mathrm{~h}$. A stock solution aliquot was diluted with ethanol in order to prepare the ABTS ${ }^{*+}$ radical working solution, with a final absorbance of $0.70 \pm 0.02$ measured at $734 \mathrm{~nm}$. Extracts were diluted in ethanol (1:25), except for the guarana extract, which was measured in its pure form. A $10 \mu \mathrm{l}$ aliquot of the diluted or pure sample was added to $990 \mu \mathrm{l}$ of $\mathrm{ABTS}^{*+}$, producing a decrease in the absorbance of $20-80 \%$ at $734 \mathrm{~nm}$ within $6 \mathrm{~min}$. The result for TEAC was obtained by comparing the corresponding percent reduction in absorbance with the Trolox concentration-response curve, expressing the result as the mass of extract which produces the same percent reduction in absorbance as the $1 \mathrm{mM}$ Trolox solution. All the analyses were carried out in triplicate.

\subsubsection{DPPH assay}

The DPPH method (BRAND-WILLIAMS et al., 1995) is based on the capture of DPPH (2,2-diphenyl-1-picrylhydrazyl) by antioxidants. Ethanol was used as the blank and the assay was carried out using $3.9 \mathrm{~mL}$ of DPPH solution and $0.1 \mathrm{~mL}$ of extract samples. The decrease in absorbance was measured at $515 \mathrm{~nm}$ using a UV-Vis spectrophotometer (PerkinElmer's LAMBDA35, USA) after 15,30 and 45 minutes. The results for the DPPH assay were expressed as the amount of extract necessary $(\mathrm{mg} / \mathrm{L})$ to decrease the initial DPPH concentration (\%) in up to $45 \mathrm{~min}$. All the analyses for each extract were carried out in triplicate.

\subsection{Determination of the total phenols}

The total phenol concentration of the extracts was measured in a UV-Vis spectrophotometer (PerkinElmer's LAMBDA35, USA) based on a colorimetric oxidation/reduction reaction as described by Woisky and Salatino (1998), using gallic acid as the standard. The Folin-Ciocalteu reagent was diluted in distilled water $(1: 10)$ and the extract samples diluted in ethanol. A $0.5 \mathrm{~mL}$ aliquot of the diluted sample was transferred to a test tube and $2.5 \mathrm{~mL}$ of Folin-Ciocalteu reagent added. The mixture was allowed to rest for 5 minutes, $2 \mathrm{~mL}$ of $4 \%$ sodium carbonate added, and the tubes maintained in the dark for 2 hours. Ethanol was used as the blank and the results expressed as $\mathrm{mg}$ gallic acid/g extract (mg GA/g extract), measured at $760 \mathrm{~nm}$. All tests for each extract were carried out in triplicate.

\subsection{Antimicrobial activity}

The disk diffusion sensitivity test was used to determine antimicrobial activity of the extracts. Escherichia coli (ATCC 25922) and Staphylococcus aureus (ATCC 29213), obtained from the Andre Tosello Foundation-Tropical Crops Collection (Campinas, Brazil) were used for this study. These cultures were regenerated by transferring a $100 \mu \mathrm{l}$ aliquot of each bacterial strain to $10 \mathrm{~mL}$ of $\mathrm{BHI}$ broth, and incubating at $37^{\circ} \mathrm{C}$ for $24 \mathrm{~h}$ up to the end of the growth exponential phase. After incubation, the bacterial strain suspensions were standardized by adjusting to 0.5 on the Mac Farland scale, which corresponds to $0.08-0.10$ of absorbance $\left(1 \times 10^{8} \mathrm{CFU} / \mathrm{mL}\right)$ using a spectrophotometer at $625 \mathrm{~nm}$. Filter paper disks ( $0.3 \mathrm{~cm}$ diameter) were soaked in $15 \mathrm{~mL}$ of each pure extract. Muller Hinton agar plates were inoculated with the bacterial suspension preparations, and sterile swabs used to spread the bacterial suspension over the whole plate, without leaving any uncovered areas. Filter paper disks were laid on the inoculated plate surface and the plates incubated for 24 hours at $37^{\circ} \mathrm{C}$. Inhibition zones were then observed as surrounding clear areas, considered as the measurement of antimicrobial activity. Chloramphenicol (2.5\%) was used as the control antibiotic. All analyses were carried out in triplicate.

\subsection{Statistical analyses}

The results were analysed by a multifactor analysis of variance with $95 \%$ least significant difference intervals (LSD), using the Statgraphics ${ }^{\circledR}$ Plus 5.1. (Manugistics Corp., Rockville, MD, USA). 


\section{Results and discussion}

\subsection{Optical properties: colour}

Table 1 shows the differences in the colour parameters of the extracts, monitored in terms of the CIEL* $a^{*} b^{*}$ colour coordinates, obtained from the sample reflection spectra. The highest $\left(L^{*}\right)$ values were found for the rosemary $(59.20 \pm 0.28)$ and guarana (56.63 \pm 0.54$)$ extracts, showing significant differences $(p<0.05)$ as compared to the cinnamon (49.14 \pm 0.56$)$ and boldo leaves $(31.10 \pm 2.65)$ extracts. Significant differences $(p<0.05)$ were observed between all the extracts for the parameter of $a^{*}$. These values varied from $9.92 \pm 0.22(+=$ red) to $-9.78 \pm 0.70$ ( $-=$ green), for the cinnamon and boldo leaves extracts, respectively. Furthermore the values for $b^{*}$ varied from 42-44 (guarana-cinnamon extracts) to 51 (boldo leaves and rosemary extracts) showing a significant difference $(p<0.05)$, meaning that these extracts were more yellow.

\subsection{Ultraviolet-visible (UV-Vis) absorption}

The UV-Vis spectra of the boldo leaves, guarana, rosemary and cinnamon extracts are shown in Figure 1. All the extracts showed the first absorption band at about 272-283 nm, which increased in absorption intensity as the value for $L^{*}$ (lightness) decreased. In this case, it is remarkable that the boldo and cinnamon extracts showed the best barrier against UV light. A second absorption band was observed between 340 - $370 \mathrm{~nm}$ for the rosemary and boldo extracts, respectively, which showed the highest $b^{*}$ $(+=$ yellow) values. These results reflect the interactions between the colour and the UV-Vis parameters. From the practical point of view, these results are interesting because they indicate that these extracts can be used as agents to prevent the lipid oxidation induced by UV light in food.

\subsection{Gas Chromatography/Mass Spectrometry (GC-MS) profile}

The volatile compounds of each extract were analysed by GC-MS.

A total of 15 components (eucalyptol or 1,8 cineole, linalool, camphor, $\alpha$-pinene, terpinen-4-ol, camphene, $\beta$-pinene, D-limonene, $\rho$-cymene, $n$-hexadecanoic acid, endo-borneol, L- $\alpha$-terpineol, caryophyllene, bornyl acetate and tetradecanal) were observed as the main compounds of the rosemary extract in this study. Other authors (VICENTE et al., 2013; JEMIA et al., 2013) also identified 1,8 cineole, camphor, borneol and linalool, amongst others, as the main compounds in the rosemary extract.

In the boldo extract, the main compounds identified in this study were 1,8-cineol, $\rho$-cymene, phytol, eicosanoic acid, cis,cis,cis-7,10,13-hexadeca trienal and $\alpha$-irone. Likewise, Valle et al. (2005), using GC-MS, identified limonene, p-cymene, thymol, spathulenol, terpinen-4-o, methyleugenol, stearic acid (isomere) and stearic acid (traces), amongst others, as the main compounds of the boldo extract.

On the other hand, only a limited number of compounds were found in the cinnamon extract in this study, identifying cinnamaldehyde and $\alpha$-copaene. The presence of cinnamaldehyde coincides with data found by other authors, such as Jin and Cho (2011), who

Table 1. CIE- $L^{*} a^{*} b^{*}$ colour coordinates of the extracts: mean values with the standard deviations in brackets.

\begin{tabular}{ccccc} 
Sample & Boldo & Cinnamon & Rosemary & Guarana \\
\hline$L^{*}$ & $31.10(2.65)^{\mathrm{a}}$ & $49.14(0.56)^{\mathrm{b}}$ & $59.20(0.28)^{\mathrm{c}}$ & $56.63(0.54)^{\mathrm{c}}$ \\
$\mathrm{a}^{*}$ & $-9.78(0.70)^{\mathrm{a}}$ & $9.92(0.22)^{\mathrm{b}}$ & $-7.66(0.06)^{\mathrm{c}}$ & $-1.59(0.16)^{\mathrm{d}}$ \\
$\mathrm{b}^{*}$ & $51.32(4.09)^{\mathrm{b}}$ & $44.72(0.30)^{\mathrm{a}}$ & $51.65(0.16)^{\mathrm{b}}$ & $42.00(0.46)^{\mathrm{a}}$ \\
\hline
\end{tabular}

Values with different letters in the same row differ significantly. Level of significance: $95.0 \%$.

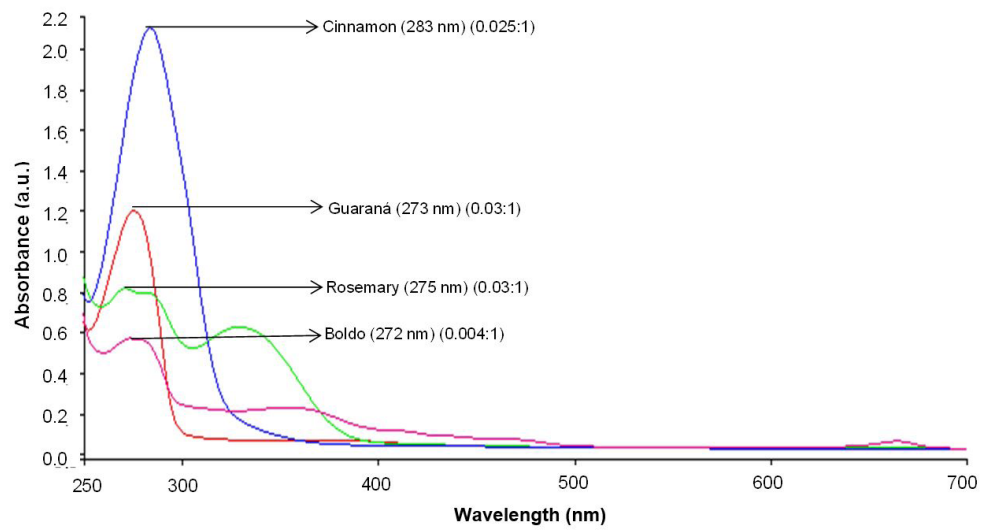

Figure 1. UV-Vis spectra for the extract samples. The absorption band and dilution ratio (extract:ethanol) are shown in brackets. 
prepared aqueous extractions of culinary herbs and spices (including rosemary and cinnamon).

Moreover, the results found for the guarana extract in this study showed caffeine as the main component, with other components appearing as traces. Schimpl et al. (2013) reported that guarana contained $6 \%$ of caffeine, with other purinic alkaloids in smaller proportions (below $0.3 \%$ ): theobromine (3,7-dimethylxanthine) and theophylline (1,3-dimethyl-xanthine).

\subsection{Antioxidant activity}

\subsubsection{TEAC (Trolox-Equivalent-Antioxidant-Capacity) assay}

Table 2 shows the results obtained in the TEAC assay at different times (1, 3, 6 min). The concentrationresponse curve at 6 min used in this analysis after the mixture of the Trolox and ABTS showed a good response for linearity $\left(R^{2}>0.9939\right)$.

The Boldo extract showed the highest relevant antioxidant capacity $(6.66 \pm 0.17 \mathrm{mM})$ as compared to the other extracts studied $(p<0.05)$. The strong antioxidant activity of the boldo extract may be related to the presence of 1,8-cineole and phytol compounds, previously identified in the GC-MS analysis, and reported earlier by Valle et al. (2004), Mazutti et al. (2008) and Netscher (2007), as compounds with antioxidant activity in boldo extract.

On the other hand, the rosemary extract had higher antioxidant capacity $(3.69 \pm 0.42 \mathrm{mM})$ than the cinnamon and guarana extracts ( $p<0.05)$. Ojeda-Sana et al. (2013) reported good antioxidant activity for $\alpha$-pinene and 1,8-cineole, compounds found in the rosemary extract by GC-MS in the present study.

\subsubsection{DPPH assay}

Table 2 shows the results obtained in the DPPH assay at different times (15, 30 and $45 \mathrm{~min})$, where the DPPH concentration-response curve at $515 \mathrm{~nm}$ showed a good response for linearity $\left(R^{2}>0.9975\right)$.
The rosemary extract showed higher free radical scavenging capacity $(0.80 \pm 0.14 \mathrm{mg} / \mathrm{L})$ than all the other extracts $(p<0.05)$. However the Boldo extract showed much greater radical scavenging capacity $(0.56 \pm 0.05 \mathrm{mg} / \mathrm{L})$ than the cinnamon and guarana extracts $(p<0.05)$, the latter two showing similar DPPH values $(0.23$ and $0.26 \mathrm{mg} / \mathrm{L}$, respectively).

\subsection{Determination of the total phenolic content}

The determination of the total phenolic content showed no significant differences between the extracts $(p>0.05)$ (Table 2). The cinnamon and guarana ethanolic extracts showed the highest total phenolic contents, with values of 172 and $139 \mathrm{mg} \mathrm{GA} / \mathrm{g}$ extract, respectively, while lower total phenolic contents of 115 and $108 \mathrm{mg} \mathrm{GA} / \mathrm{g}$ extract were found for the rosemary and boldo extracts, respectively. Przygodzka et al. (2013) investigated the antioxidant capacities of ethanolic and ethanol/water extracts of 12 different selected spices, using different methods. They reported similar results to the present study with respect to the cinnamon extract (160 mg GA/g extract), and concluded from their results that, for industrial purposes, ethanolic or aqueous ethanol extracts would probably be better than the more commonly employed solvent of methanol. Majhenic et al. (2007) studied the phenolic compound content of guarana seed extracts. They found that the total phenolic compounds extracted with the different solvent mixtures (distilled water, methanol, 35\% acetone and $60 \%$ ethanol) ranged from 119 to $186 \mathrm{mg} \mathrm{GA} / \mathrm{g}$ extract. When $60 \%$ ethanol was used as the extraction solvent, the phenolic compound content ranged from 166 to $172 \mathrm{mg} \mathrm{GA} / \mathrm{g}$ extract, very similar to the results found in the present study $(139 \pm 0.028 \mathrm{mg} \mathrm{GA} / \mathrm{g}$ extract) for the guarana extract.

\subsection{Antimicrobial activity}

Figure 2 shows the qualitative results obtained for the antimicrobial activity of the extracts against selected microorganisms by the disk diffusion method.

Table 2. Results obtained for the extracts in the Trolox equivalent antioxidant capacity (TEAC) and DPPH assays at specific time points and for the Folin-Ciocalteu assay (Mean values with the standard deviations in brackets).

\begin{tabular}{|c|c|c|c|c|c|}
\hline Sample & & Rosemary & Boldo & Cinnamon & Guarana \\
\hline \multirow{3}{*}{$\begin{array}{l}\text { TEAC } \\
(\mathrm{mM})\end{array}$} & $1 \mathrm{~min}$ & $2.96(0.04)^{a, x}$ & $5.50(0.01)^{b, x}$ & $2.53(0.11)^{c, x}$ & $0.25(0.01)^{d, x}$ \\
\hline & $3 \mathrm{~min}$ & $3.32(0.24)^{a, y}$ & $6.23(0.21)^{b, y}$ & $2.75(0.07)^{c, y}$ & $0.26(0.01)^{d, y}$ \\
\hline & $6 \min$ & $3.69(0.42)^{a, z}$ & $6.66(0.17)^{\mathrm{b}, \mathrm{z}}$ & $2.86(0.06)^{c, z}$ & $0.26(0.01)^{d, z}$ \\
\hline \multirow{3}{*}{$\begin{array}{l}\text { DPPH } \\
(\mathrm{mg} / \mathrm{l})\end{array}$} & $15 \mathrm{~min}$ & $0.37(0.02)^{a, x}$ & $0.23(0.02)^{b, x}$ & $0.06(0.01)^{a, x}$ & $0.10(0.01)^{c, x}$ \\
\hline & $30 \mathrm{~min}$ & $0.48(0.02)^{a, y}$ & $0.37(0.03)^{b, y}$ & $0.13(0.04)^{a, y}$ & $0.14(0.01)^{c, y}$ \\
\hline & $45 \mathrm{~min}$ & $0.80(0.14)^{a, z}$ & $0.56(0.05)^{b, z}$ & $0.23(0.02)^{c, z}$ & $0.26(0.04)^{c, z}$ \\
\hline $\begin{array}{l}\text { Folin-Ciocalteu } \\
\text { (mg GA/g extract) }\end{array}$ & --- & $115.00(0.01)^{a}$ & $108.00(0.04)^{a}$ & $172.00(0.03)^{a}$ & $139.00(0.03)^{a}$ \\
\hline
\end{tabular}

The same superscript (abc) compares different extracts horizontally and (xyz) compare them vertically at different times in the LSD test. Values with different letters differ significantly in same row. Level of significance: $95.0 \%$. 



Figure 2. Inhibition of bacterial growth (E. Coli and S. Aureus) by the boldo of Chile (Peumus boldus molina), cinnamon (Cinnamomum sp.), guarana (Paullinia cupana) and rosemary (Rosmarinus officinalis) extracts.

Chloramphenicol, used as the antibiotic control, showed the highest (sensitive) inhibitory effect in comparison with all the extracts studied. According to the results of the present study, the boldo, rosemary, guarana and cinnamon extracts showed slight antimicrobial activity against $S$. aureus, but no antimicrobial activity against the E. coli strain tested. Several investigations have reported that gram-positive bacteria are more sensitive to spice and herb extracts or plant essential oils than gram-negative bacteria (BURT, 2004). These results can be attributed to the lipopolysaccharides in the cell wall of gram-negative bacteria, which may prevent active components from reaching the membrane (WEERAKKODY et al., 2010; KALEMBA; KUNICKA, 2003). Ho et al. (2010) evaluated plant extracts with antimicrobial potential obtained from Orthosiphon stamineus using methanol and reported weak antimicrobial activity against $S$. aureus and $B$. cereus. Contrary to these authors, Basile et al. (2005) showed that the ethanolic extract of guarana seeds had interesting activity against eight of the 10 bacterial strains tested, and was more active against $E$. coli than against $S$. aureus.

\section{Conclusions}

This investigation demonstrated the antimicrobial and antioxidant activities of conventional (cinnamon and rosemary) and non-conventional (boldo leaves and guarana) extracts. Interactions between the UV-Vis absorption and the luminosity $\left(L^{*}\right)$ of the extracts were detected. The GC-MS profile allowed for identification of the volatile components of all the extracts. The investigation did not find a direct relation between the total phenolic content and antioxidant activity, the cinnamon and guarana extracts showed the highest values for the total phenolic content, whereas the boldo leaves and rosemary extracts presented the highest relevant antioxidant capacities according to the TEAC and DPPH assays, respectively. Finally, all the extracts showed antimicrobial activity against $S$. aureus but not against the $E$. coli strains. The results obtained showed good potential for both the non-conventional and conventional extracts as antioxidant and antimicrobial agents for future incorporation in food packaging materials.

\section{Acknowledgements}

The authors are grateful to the São Paulo Research Foundation (FAPESP) for the financial support (CEPID FoRC 13/07914-8), and for the postdoctoral fellowship awarded to Jeannine Bonilla Lagos (14/03288-8), and to the Brazilian National Council for Scientific and Technological Development (CNPq) for the Research fellowship awarded to Paulo J. A. Sobral. They are also grateful to Prof. Dr. Emanuel Carrilho and Dra Luciana Teresa Dias Cappelini of the Institute of Chemistry of the São Carlos-University of São Paulo for technical assistance in the GC-MS analyses, and to the multipurpose microbiology laboratory of the University of São Paulo, Pirassununga, for providing the infrastructure and technical assistance for the microbiological analyses.

\section{References}

BASILE, A.; FERRARA, L.; DEL PEZZO, M.; MELE, G.; SORBO, S.; BASSI, P.; MONTESANO, D. Antibacterial and antioxidant activities of ethanol extract from Paullinia cupana Mart. Journal 
Antioxidant and antimicrobial properties of ethanolic extracts of guarana, boldo, rosemary and cinnamon Bonilla, J.; Sobral, P. J. A.

of Ethnopharmacology, Lausanne, v. 102, n. 1, p. 32-36, 2005. PMid:16040216. http://dx.doi.org/10.1016/j.jep.2005.05.038.

BONILLA, J.; ATARÉS, L.; VARGAS, M.; CHIRALT, A. Effect of essential oils and homogenization conditions on properties of chitosan-based films. Food Hydrocolloids, Oxford, v. 26, n. 1, p. 9-16, 2012. http://dx.doi.org/10.1016/j.foodhyd.2011.03.015.

BONILLA, J.; SOBRAL, P. J. A. Investigation of the physicochemical, antimicrobial and antioxidant properties of gelatin-chitosan edible film mixed with plant ethanolic extracts. Food Bioscience, London, v. 16, p. 17-25, 2016. http://dx.doi.org/10.1016/j.fbio.2016.07.003.

BONILLA, J.; SOBRAL, P. J. A. Antioxidant and physicochemical properties of blended films based on gelatin-sodium caseinate activated with natural extracts. Journal of Applied Polymer Science, Hoboken, v. 134, n. 7, p. 44467, 2017. http://dx.doi. org/10.1002/app.44467.

BRAND-WILLIAMS, W.; CUVELIER, M. E.; BERSET, C. Use of a free radical method to evaluate antioxidant activity. LebensmittelWissenschaft \& Technologie, London, v. 28, n. 1, p. 25-30, 1995. http://dx.doi.org/10.1016/S0023-6438(95)80008-5.

BUBONJA-SONJE, M.; GIACOMETTI, J.; ABRAM, M. Antioxidant and antilisterial activity of olive oil, cocoa and rosemary extract polyphenols. Food Chemistry, London, v. 127, n. 4, p. 18211827, 2011. http://dx.doi.org/10.1016/j.foodchem.2011.02.071.

BURT, S. Essential oils: their antibacterial properties and potential applications in foods: a review. International Journal of Food Microbiology, Amsterdam, v. 94, n. 3, p. 223-253, 2004. PMid:15246235. http://dx.doi.org/10.1016/j.ijfoodmicro.2004.03.022.

GIBIS, M.; WEISS, J. Antioxidant capacity and inhibitory effect of grape seed and rosemary extract in marinades on the formation of heterocyclic amines in fried beef patties. Food Chemistry, London, v. 134, n. 2, p. 766-774, 2012. PMid:23107689. http:// dx.doi.org/10.1016/j.foodchem.2012.02.179

GIRARDI, N. S.; GARCÍA, D.; ROBLEDO, S. N.; PASSONE, M. A.; NESCI, A.; ETCHEVERRY, M. Microencapsulation of Peumus boldus oil by complex coacervation to provide peanut seeds protection against fungal pathogens. Industrial Crops and Products, Amsterdan, v. 92, p. 93-101, 2016.

HO, C.; NORYATI, I.; SULAIMAN, S.; ROSMA, A. In vitro antibacterial and antioxidant activities of Orthosiphon stamineus Benth extracts against food-borne bacteria. Food Chemistry, London, v. 122 , n. 4, p. 1168-1172, 2010. http://dx.doi.org/10.1016/j. foodchem.2010.03.110.

HOQUE, M. S.; BENJAKUL, S.; PRODPRAN, T. Properties of film from cuttlefish (Sepia pharaonis) skin gelatin incorporated with cinnamon, clove and star anise extracts. Food Hydrocolloids, Oxford, v. 25, n. 5, p. 1085-1097, 2011. http://dx.doi.org/10.1016/j. foodhyd.2010.10.005.

JEMIA, M. B.; TUNDIS, R.; MAGGIO, A.; ROSSELLI, S.; SENATORE, F.; MENICHINI, F.; BRUNO, M.; KCHOUK, M. E.; LOIZZO, M. R. NMR-based quantification of rosmarinic and carnosic acids,
GC-MS profile and bioactivity relevant to neurodegenerative disorders of Rosmarinus officinalis L. extracts. Journal of Functional Foods, Amsterdam, v. 5, n. 4, p. 1873-1882, 2013. http://dx.doi.org/10.1016/j.jff.2013.09.008.

JIN, S.; CHO, K. Water extracts of cinnamon and clove exhibits potent inhibition of protein glycation and anti-atherosclerotic activity in vitro and in vivo hypolipidemic activity in zebra fish. Food and Chemical Toxicology, Amsterdam, v. 49, n. 7, p. 1521-1529, 2011. PMid:21443916. http://dx.doi.org/10.1016/j. fct.2011.03.043.

KALEMBA, D.; KUNICKA, A. Antibacterial and antifungal properties of essential oils. Current Medicinal Chemistry, Schiphol, v. 10, n. 10, p. 813-829, 2003. PMid:12678685. http:// dx.doi.org/10.2174/0929867033457719.

MAJHENIC, L.; SKERGET, M.; KNEZ, Z. Antioxidant and antimicrobial activity of guarana seed extracts. Food Chemistry, London, v. 104, n. 3, p. 1258-1268, 2007. http://dx.doi.org/10.1016/j. foodchem.2007.01.074.

MATHEW, S.; ABRAHAM, T. E. Studies on the antioxidant activities of cinnamon (Cinnamomum verum) bark extracts, through various in vitro models. Food Chemistry, London, v. 94, n. 4, p. 520-528, 2006. http://dx.doi.org/10.1016/j.foodchem.2004.11.043.

MAZUTTI, M.; MOSSI, A. J.; CANSIAN, R. L.; CORAZZA, M.-L.; DARIVA, C.; OLIVEIRA, J. V. Chemical profile and antimicrobial activity of Boldo (Peumus boldus molina) extracts obtained by compressed carbon dioxide extraction. Brazilian Journal of Chemical Engineering, São Paulo, v. 25, n. 2, p. 427-434, 2008. http://dx.doi.org/10.1590/S0104-66322008000200020.

MOURE, A.; CRUZ, J. M.; FRANCO, D.; DOMÍNGUEZ, J. M.; SINEIRO, J.; DOMÍNGUEZ, H.; NÚNEZ, M. J.; PARAJÓ, J. C. Review: natural antioxidants from residual sources. Food Chemistry, London, v. 72, n. 2, p. 145-171, 2001. http://dx.doi. org/10.1016/S0308-8146(00)00223-5.

NETSCHER, T. Synthesis of vitamin E. Vitamins and Hormones, New York, v. 76, p. 155-202, 2007. PMid:17628175. http://dx.doi. org/10.1016/S0083-6729(07)76007-7.

OJEDA-SANA, A. M.; VAN BAREN, C. M. V.; ELECHOSA, M. A.; JUÁREZ, M. A.; MORENO, S. New insights into antibacterial and antioxidant activities of rosemary essential oils and their main components. Food Control, Guildford, v. 31, n. 1, p. 189-195, 2013. http://dx.doi.org/10.1016/j.foodcont.2012.09.022.

PAPETTI, A. Isolation and characterization of antimicrobial food components. Current Opinion in Biotechnology, London, v. 23, n. 2, p. 168-173, 2012. PMid:21962391. http://dx.doi.org/10.1016/j. copbio.2011.09.001.

PRZYGODZKA, M.; ZIELINSKA, D.; CIESAROVÁ, Z.; KUKUROVÁ, $K$. Comparison of methods for evaluation of the antioxidant capacity and phenolic compounds in common spices. LWT - Food Science and Technology, Campinas, v. 58, n. 2, p. 321-326, 2013. 
Antioxidant and antimicrobial properties of ethanolic extracts of guarana, boldo, rosemary and cinnamon

Bonilla, J.; Sobral, P. J. A.

RE, R.; PELlegrinI, N.; PROTEGGente, A.; PANNAlA, A.; YANG, M.; RICE-EVANS, C. Antioxidant activity applying an improved ABTS radical cation decoloration assay. Free Radical Biology \& Medicine, New York, v. 26, n. 9-10, p. 1231-1237, 1999. PMid:10381194. http://dx.doi.org/10.1016/S0891-5849(98)00315-3.

SCHIMPL, F. C.; SILVA, J. F.; GONÇALVES, J. F. C.; MAZZAFERA, $P$. Guarana: revisiting a highly caffeinated plant from the Amazon. Journal of Ethnopharmacology, Lausanne, v. 150, n. 1, p. 14-31, 2013. PMid:23981847. http://dx.doi.org/10.1016/j.jep.2013.08.023.

TAJKARIMI, M. M.; IBRAHIM, S. A.; CLIVER, D. O. Review: antimicrobial herb and spice compounds in food. Food Control, London, v. 21, n. 9, p. 1199-1218, 2010. http://dx.doi.org/10.1016/j. foodcont.2010.02.003.

TONGNUANCHAN, P.; BENJAKUL, S.; PRODPRAN, T. Properties and antioxidant activity of fish skin gelatin film incorporated with citrus essential oils. Food Chemistry, London, v. 134, n. 3, p. 1571-1579, 2012. PMid:25005982. http://dx.doi.org/10.1016/j. foodchem.2012.03.094.

VALLE, J. M.; GODOY, C.; ASENCIO, M.; AGUILERA, J. M. Recovery of antioxidants from boldo (Peumus boldus M.) by conventional and supercritical CO2 extraction. Food Research International, Oxford, v. 37, n. 7, p. 695-702, 2004. http://dx.doi. org/10.1016/j.foodres.2003.03.001.
VALLE, J. M.; ROGALINSKI, T.; ZETZL, C.; BRUNNER, G. Extraction of boldo (Peumus boldus M.) leaves with supercritical $\mathrm{CO} 2$ and hot pressurized water. Food Research International, Oxford, v. 38, n. 2, p. 203-213, 2005. http://dx. doi.org/10.1016/j. foodres.2004.09.010.

VICENTE, G.; GARCÍA-RISCO, M. R.; FORNARI, T.; REGLERO, $\mathrm{G}$. Isolation of carsonic acid from rosemary extracts using semi-preparative supercritical fluid chromatography. Journal of Chromatography. A, Amsterdam, v. 1286, p. 208-215, 2013. PMid:23497854. http://dx.doi.org/10.1016/j.chroma.2013.02.044. WANG, R.; WANG, R.; YANG, B. Extraction of essential oils from five cinnamon leaves and identification of their volatile compound compositions. Innovative Food Science \& Emerging Technologies, Amsterdam, v. 10, n. 2, p. 289-292, 2009. http:// dx.doi.org/10.1016/j.ifset.2008.12.002.

WEERAKKODY, N. S.; CAFFIN, N.; TURNER, M. S.; DYKES, G. A. In vitro antimicrobial activity of less-utilized spice and herb extracts against selected food-borne bacteria. Food Control, London, v. 21, n. 10, p. 1408-1414, 2010. http://dx.doi.org/10.1016/j. foodcont.2010.04.014.

WOISKY, R. G.; SALATINO, A. Analysis of propolis: some parameters and procedures for chemical quality control. Journal of Apicultural Research, London, v. 37, n. 2, p. 99-105, 1998. http://dx.doi.org/10.1080/00218839.1998.11100961. 